\title{
Demonstration and Comparison of Keratin Pearl and Individual Cell Keratin in Oral Squamous Cell Carcinoma using Modified Mallory's Stain and Hematoxylin and Eosin
}

\author{
Santhosh Kumar Caliaperoumal ${ }^{1 *}$, R. Vezhavendhan ${ }^{2}$, \\ A. Santha devy ${ }^{2}$, Priyavendhan ${ }^{2}$ and Uma devi ${ }^{2}$ \\ ${ }^{1}$ Department of Dentistry,Vinayaka Mission's Medical college and Hospital, \\ Karaikal, Puducherry, India \\ ${ }^{2}$ Department of Oral Pathology, Indira Gandhi Dental College \& Hospital, Puducherry, India \\ *Corresponding author
}

\section{A B S T R A C T}

Keywords

Squamous cell carcinoma (SCC), Keratin Pearl(KP), Individual cell Keratin (ICK),modified Mallory's stain, Hematoxylin and Eosin (H\&E) stain.

\section{Article Info}

Accepted:

20 June 2016

Available Online:

10 July 2016
Observation of Keratin pearl (KP) and individual cell keratin (ICK) is a major criteria in histopathological grading of oral squamous cell carcinoma (SCC). The aim of the study was to evaluate and compare the distinct staining and identification of KP and ICK by routine Hematoxylin \& Eosin (H\&E) stain and modified Mallory's stain. The known cases of oral SCC with sufficient paraffin embedded tissue were selected. The two sections from each block were stained with H\&E stain and modified Mallory's stain. The modified Mallory's stain distinctively and clearly stained KP and ICK compared to H\&E stain. The positive staining of KP and ICK by modified Mallory's stain was statistically significant with $\mathrm{P}=0.001, \mathrm{f}=0.001$ and $\mathrm{P}=0.022, \mathrm{f}=0.034$ than $\mathrm{H} \& \mathrm{E}$ stain. Based on our observation we conclude that the positive staining of KP and ICK in oral SCC by modified Mallory's stain is statistically significant than H\&E stain. So, modified Mallory's stain can be used as an adjuvant stain along with H\&E stain in case of

\section{Introduction}

Oral squamous cell carcinoma is one of the most common oral malignant tumors comprising of 90-95\% of cases (Pindborg et al., 1990; Harrison et al., 1999). It is commonest malignancy in Indian sub continent (Pindborg et al., 1990; Parija, 1991). It is histologically graded as well, moderate and poorly differentiated tumor based on several factor (Neville et al., 2002'
Neville et al., 2002). One of the features that influence histological grading is tendency of oral SCC to form keratin (Neville et al., 2002; Shafer, 1993). Keratin is an intermediate filament protein found in the surface epithelium (Clausen et al., 1986; Tencate, 1998). Keratin in surface epithelium protects underlying connective tissue structure (Schweizer et al., 1983). The 
synthesis of keratin in epithelial cell reflects the differentiation level of normal as well as the malignant epithelial cells of carcinoma (Schweizer et al., 1983; Steinert et al., 1990; Coulombe et al., 1990). The prognosis of malignant neoplasm is relates to tumour differentiation In oral SCC the level of keratin synthesis by malignant epithelial cell would be a good predictor of differentiation, hence the prognosis (Gould, 1985; Nagle et al., 1983; Rothman, 1954). So the study of keratin pearl and individual cell keratin in oral squamous cell carcinoma by utilizing modified Mallory's stain and H \& E stain (Culling, 1963) was done.

The aim of this study was to evaluate and compare positive staining of keratin pearl and individual cell keratin using the hematoxylin \& eosin stain, modified Mallory's stain.

\section{Materials and Methods}

The histo-pathologically diagnosed cases of oral squamous cell carcinomas from "Department of Oral Pathology And Microbiology, Mahatma Gandhi PostGraduate Institute of Dental Sciences" were retrieved for the study group. The total number of 38 cases of carcinomas of study group were taken. The study group included 21 well-differentiated and 17 moderatelydifferentiated squamous cell carcinoma.

The only inclusion criterion was sufficient tissue material in paraffin blocks. The two serial sections were made of 4-5 micron thickness and stained by routine $\mathrm{H} \& \mathrm{E}$ stain and modified Mallory's stain for keratin. The staining protocol suggested by Ayoubshklar (Ayoub et al., 1963) for modified Mallory's stain was followed for all the cases.

The following criteria were analyzed to identify and compare the positive staining of keratin by H\&E stain and modified
Mallory's stain in oral squamous cell carcinoma.

\section{Criteria's}

A clear identification of keratin pearl.

A clear identification of Individual cell keratin.

The data was subjected to statistical analysis by SPSS software version 16 .

\section{Results and Discussion}

The study of 38 cases of oral SCC which were stained by modified Mallory's stain and $H \& E$ stain. The stained sections were analyzed for distinct and positive staining of $\mathrm{KP}$ and ICK.

The modified Mallory's stain showed a positive staining of KP in $28(73.6 \%)$ cases, whereas H\&E stain showed positive staining in 20(52.6\%) cases (Table-1, Graph-1).

The positivity of KP was statistically significant for modified Mallory's stain than $H \& E$ with chi-square value of $15.079, p$ value of $p=0.000$ and Fisher's exact test: $f$ $=0.000$ (Table-2). This indicates that there was a statistically significant positive staining of KP by modified Mallory's stain than H\&E stain in oral SCC.

The modified Mallory's stain showed a positive staining of ICK in $23(60.5 \%)$ cases, whereas $H \& E$ stain showed positive staining in $13(34.2 \%)$ cases (Table-3, Graph-2).

The positivity of ICK was statistically significant in modified Mallory's stain than $\mathrm{H} \& \mathrm{E}$ with chi-square value of $12.887, \mathrm{p}$ value of $p=0.000$ and Fisher's exact test: $f$ $=0.000$ (Table-4). This Indicates there was a statistically significant positive staining of ICK by modified Mallory's stain than H\&E stain in oral SCC. 
Table.1 Keratin Pearl staining in oral squamous cell carcinoma by hematoxylin and eosin stain and modified Mallory's stain

\begin{tabular}{|l|c|c|}
\hline & H\&E Stain & Modified Papanicolou Stain \\
\hline Positive Staininig & 20 & 28 \\
\hline Negative Staining & 18 & 10 \\
\hline TOTAL & 38 & 38 \\
\hline
\end{tabular}

Table.2 Statistical analysis of Keratin Pearl Staining with H\&E and Modified Mallory’s stain

\begin{tabular}{|c|c|c|c|c|c|c|}
\hline \multicolumn{7}{|l|}{ Cross tabulation } \\
\hline COUNT & \multicolumn{6}{|c|}{ Keratin Pearl Staining Mod.Mallory's } \\
\hline \multirow{4}{*}{$\begin{array}{l}\text { Keratin Pearl Staining } \\
\text { H\&E }\end{array}$} & \multirow{2}{*}{\multicolumn{2}{|c|}{ Negative }} & & & Positive & Total \\
\hline & & & \multicolumn{2}{|c|}{10} & 8 & 18 \\
\hline & \multicolumn{2}{|l|}{ Positive } & \multicolumn{2}{|l|}{0} & 20 & 20 \\
\hline & \multicolumn{2}{|l|}{ Toatl } & \multicolumn{2}{|l|}{10} & 28 & 38 \\
\hline \multicolumn{7}{|l|}{ Chi-Square Tests } \\
\hline & value & df & & $\begin{array}{l}\text { Asymp. Sig } \\
\text { (2-sided) }\end{array}$ & $\begin{array}{l}\text { Exact Sig } \\
\text { (2-sided) }\end{array}$ & $\begin{array}{l}\text { Exact Sig } \\
\text { (1-sided) }\end{array}$ \\
\hline Pearson chi-Square & 15.079 & 1 & & .000 & & \\
\hline Fisher's Exact Test & & & & & .000 & .000 \\
\hline
\end{tabular}

Table.3 Individual cell Keratin staining in oral squamous cell carcinoma by hematoxylin and eosin stain and modified Mallory’s stain

\begin{tabular}{|l|c|c|}
\hline & H \& E Stain & Modified Mallory's Stain \\
\hline Positive Staininig & 13 & 23 \\
\hline Negative Staining & 25 & 15 \\
\hline TOTAL & 38 & 38 \\
\hline
\end{tabular}

Table.4 Statistical analysis of Individual cell Keratin Staining with H\&E and Modified Mallory's stain

\begin{tabular}{|c|c|c|c|c|c|}
\hline \multicolumn{6}{|l|}{ Cross tabulation } \\
\hline COUNT & \multicolumn{5}{|c|}{ Individual cell Keratin Staining Mod.Pap } \\
\hline \multirow{4}{*}{$\begin{array}{l}\text { Individual cell } \\
\text { Keratin Staining } \\
\text { H\&E }\end{array}$} & \multicolumn{3}{|c|}{\begin{tabular}{l|l} 
& Negative \\
\end{tabular}} & Positive & Total \\
\hline & \multicolumn{2}{|l|}{ Negative } & 15 & 10 & 25 \\
\hline & \multicolumn{2}{|l|}{ Positive } & 0 & 13 & 13 \\
\hline & \multicolumn{2}{|l|}{ Toatl } & 15 & 23 & 38 \\
\hline \multicolumn{6}{|l|}{ Chi-Square Tests } \\
\hline & value & df & $\begin{array}{l}\text { Asymp. Sig(2- } \\
\text { sided) }\end{array}$ & $\begin{array}{l}\text { Exact } \operatorname{Sig}(2- \\
\text { sided })\end{array}$ & $\begin{array}{l}\text { Exact Sig(1- } \\
\text { sided })\end{array}$ \\
\hline Pearson chi-Square & 12.887 & 1 & .000 & & \\
\hline Fisher's Exact Test & & & & .000 & .000 \\
\hline
\end{tabular}


Graph.1 Keratin Pearl staining in oral squamous cell carcinoma by hematoxylin and eosin stain and modified Mallory's stain

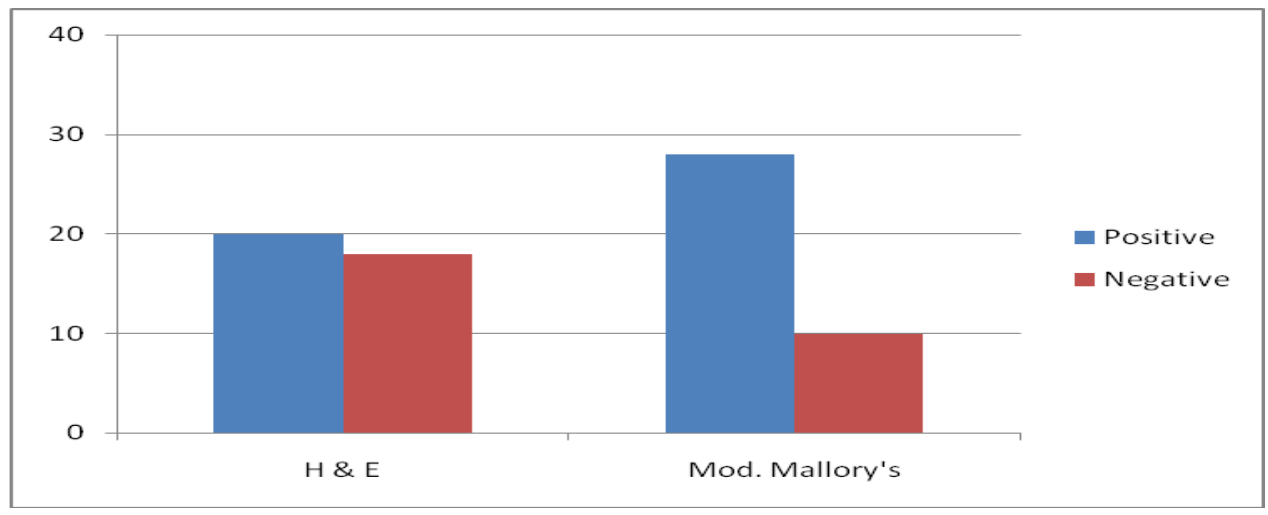

Graph.2 Individual cell Keratin staining in oral squamous cell carcinoma by hematoxylin and eosin stain and modified Mallory's stain

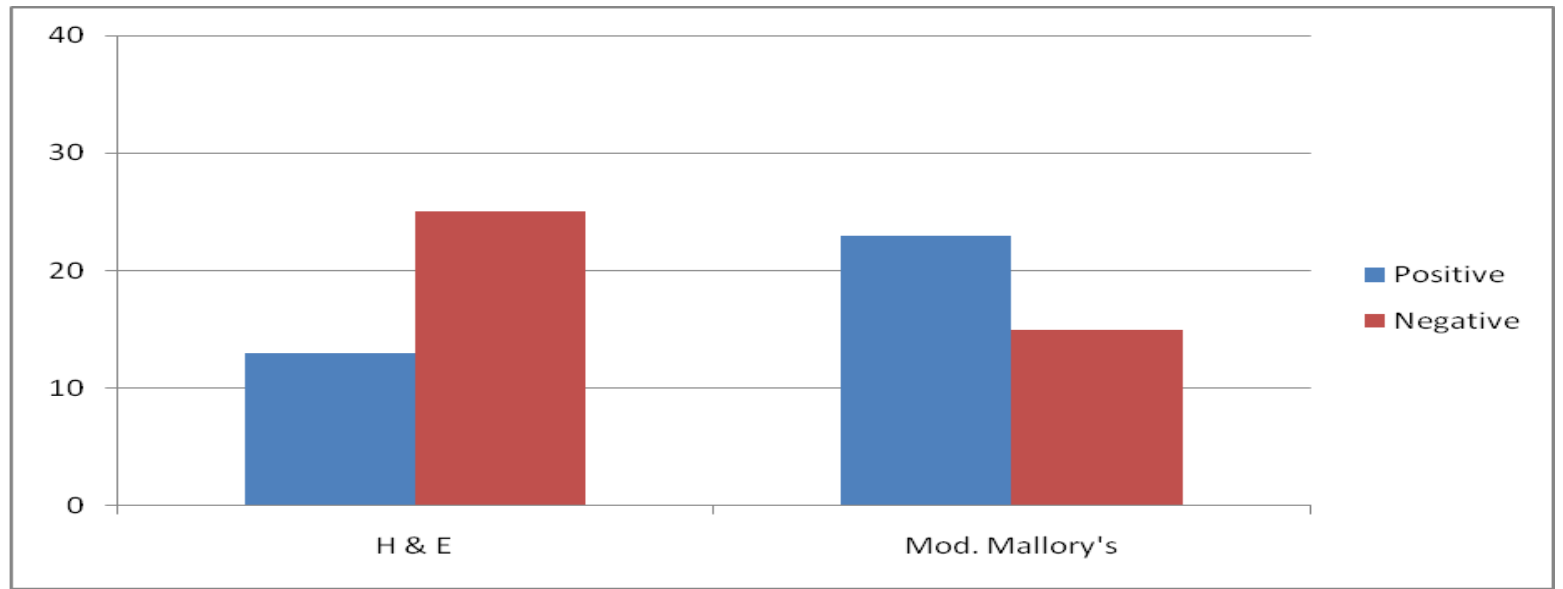

Fig.1 Keratin pearl staining in oral squamous cell carcinoma by H\&E (a) and Modified Mallory's (b) stain.
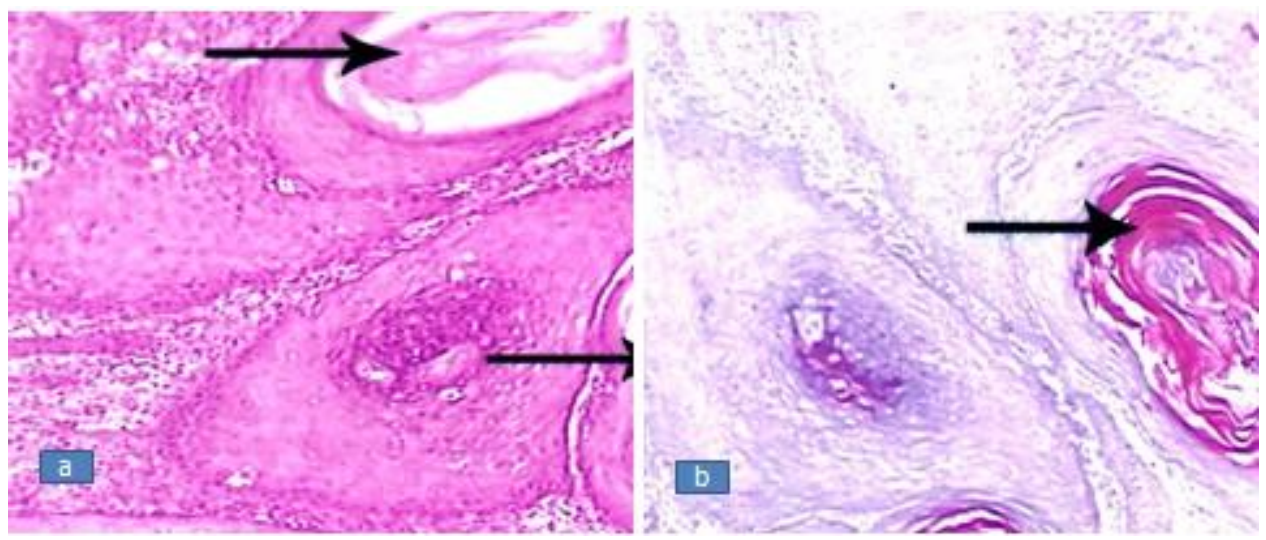
Fig.2 Individual cell Keratin pearl staining in oral squamous cell carcinoma by H\&E (a) and Modified Mallory's (b) stain.

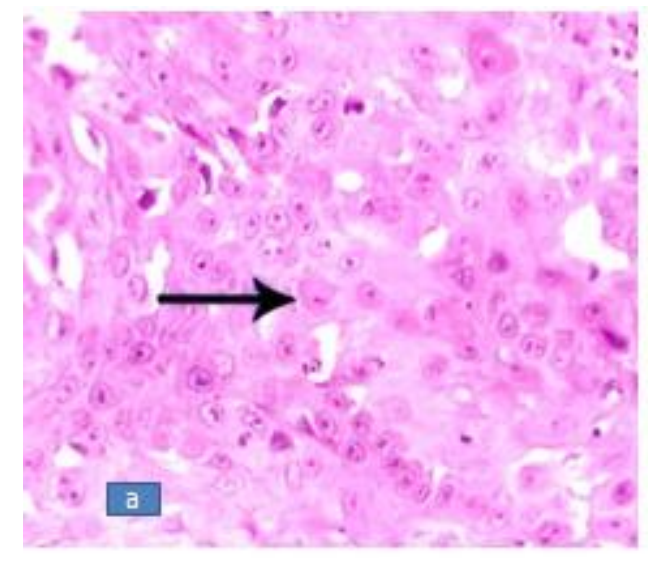

The better differentiated oral SCC has a better prognosis. The level of keratin synthesis is one of the factors in grading oral SCC. Hence the study was carried out with an aim to evaluate and compare positive staining of keratin pearl and individual cell keratin in the oral squamous cell carcinoma with H\&E and modified Mallory's stain.

The control group consisting of 10 cases showed in the statistical analysis, that there is no degree of significance using Modified Mallory's stain in demonstrating keratin. This may probability due to paucity of number of samples taken for the control group.

The staining of keratin pearl was significantly positive at $\mathrm{p}=0.000$ and fisher's test of $\mathrm{f}=0.000$ in Modified Mallory's stain than $\mathrm{H} \& \mathrm{E}$ in oral SCC group. This can be applied in the easy identification of KP and grading of oral SCC. Similar observation of high degree of intensity of staining of keratin in modified PAP stain was reported by Santis-Shklar and Ayoub-shklar. This concurs with our study.

The individual cell keratin was significantly positive at $p=0.000$ and fisher's test of $f$ $=0.000$ in Modified Mallory's stain

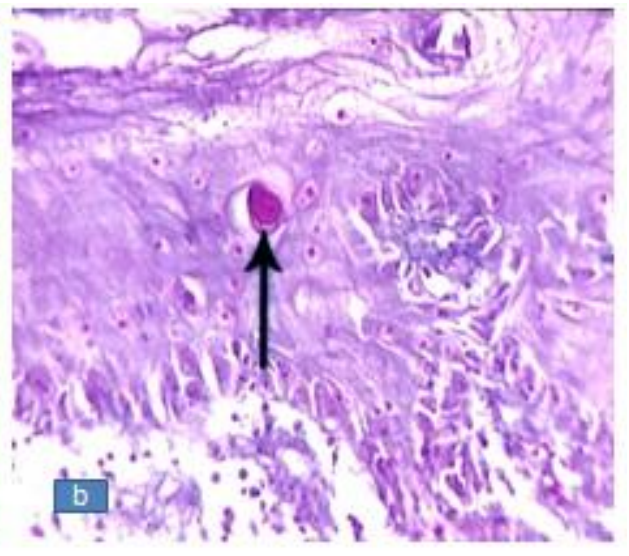

compared to the $\mathrm{H} \& \mathrm{E}$ stain in oral SCC group. This can be positively used in elucidating differentiation level of oral SCC.

It has been reported by many studies that there was varying and unusual expression of keratin molecules in malignant epithelial cells that are not present in normal epithelial cell. The different nature of keratin molecule expression in malignant epithelial cell, probably explains the difference in staining quality of modified Mallory's stain. It was interesting to note that Modified Mallory's stain was able to demonstrate some of those unusual keratin filaments of carcinoma cases. The variation in staining quality depends on degree of compactness variation of keratin during the progression of the malignancy.

The present study has proved that the Modified Mallory's stain has more significant association with demonstration of keratin pearl and individual cell keratinization well and moderately differentiated squamous cell carcinoma than the routine $\mathrm{H} \& \mathrm{E}$ stain. This stain can be favorably used to demonstrate the keratin pearl and individual cell keratin areas, hence the differentiation level of epithelial cells in oral SCC. 
In conclusion, the efficacy of distinct demonstration of Keratin Pearl and Individual Cell Keratin in oral SCC by modified Mallory's stain is better than H\&E stain, but $\mathrm{H} \& \mathrm{E}$ is routine standard and simple stain in demonstrating other details like nucleus, connective tissue structures. So along with H\&E stain, an adjuvant stain of modified Mallory's stain can be used in cases of oral SCC.

\section{References}

Ayoub, P., Shklar, G. 1963. A modification of Mallory connective tissue stain as a stain for keratin. Oral Pathol. Oral. Surg. Oral Med., 16: 580-581.

Bancroft, D., John \& Gamble Marilyn Theory and practice of histological techniques, 2002. 149-155,109-123.

Clausen, H., Moe, D., Buschard, K. et al. 1986. Keratin proteins in human oral mucosa. J. Oral Pathol., 15: 36-42.

Coulombe, P.A., Fuchs, E. 1990. Elucidating the early stages of keratin filament assembly. J. Cell Biol., 111: 153-169.

Culling, C.F.A. 1963. Handbook of histopathologic technique, 113-126: 167-170.

Gould, V.E. 1985. The coexpression of distinct classes of intermediate filaments in human neoplasms. Arch. Pathol. Lab. Med., 109: 984-985.

Harrison, B., Louis, et al. 1999. Head and neck cancer- a multidisciplinary approach, 411-444.

Kumar Vinay, Abbas, K., Abdul, Fausto Nelson Robbins and cotran Pathologic basis of disease, $7^{\text {th }}$ edition, 2004; pp271,780-781,806-808,1242.
Nagle, R.B., McDaniel, K.M., Clark, V.A. et al. 1983. The use of antikeratin antibodies in the diagnosis of human neoplasms. Am. J. Clin. Pathol., 79: 458-466.

Neville, B.W., Day, A.T. 2002. Oral cancer and precancerous lesions. Ca Cancer J. Clin., 52: 195-215.

Neville, W., Brad, et al. 2002. Oral \& Maxillofacial pathology, $2^{\text {nd }}$ edition, 356-370.

Parija, U.R. 1991. Site and side distribution in oral cancer-An epidemiological study of 1482 cases in five years. In Oral Oncol., Vol.I. 14-18.

Pindborg, J.J. et al. 1990. Oral cancer epidemiology, etiology and pathology. 46-48, 52-54.

Rothman, S. 1954. Oral pathology-Physiology of keratinisation, 7: 1085-1090.

Santis, H., Shklar, G. 1964. A histochemical study of human oral carcinoma. Oral Pathol., 17: 84-91.

Schweizer, J., Winter, H. 1983. Keratin biosynthesis in normal mouse epithelia and in squamous cell carcinomas. $J$. Biol. Chem., 256: 13268-13272.

Shafer, G. William, et al. 1993. Textbook of oral pathology, $4^{\text {th }}$ edition, 112-130.

Steinert, P.M. Marekov, L.N. 1995. The proteins elafin, filaggrin, keratin, intermediate filaments, loricrin and small proline rich proteins 1 and 2 are isodipeptide cross linked components of the human epidermal cornified cell envelope. J. Biol. Chem., 270: 1770217711.

Tencate, A.R. 1998. Oral Mucosa. $5^{\text {th }}$ edition, 351-362.

\section{How to cite this article:}

Santhosh Kumar Caliaperoumal, R. Vezhavendhan, A. Santha devy, Priyavendhan and Uma devi. 2016. Demonstration and Comparison of Keratin Pearl and Individual Cell Keratin in Oral Squamous Cell Carcinoma using Modified Mallory's Stain and Hematoxylin and Eosin. Int.J.Curr.Microbiol.App.Sci. 5(7): 586-591. doi: http://dx.doi.org/10.20546/ijcmas.2016.507.065 